
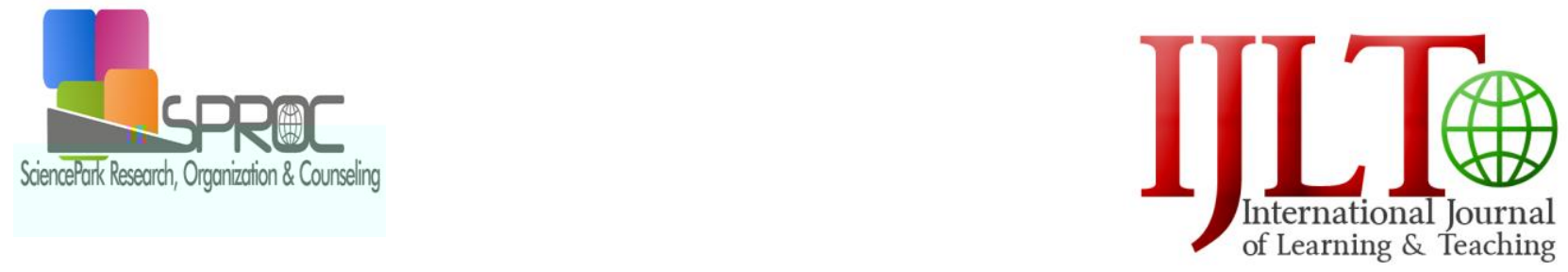

www.ij-It.eu

\title{
Determining the perceptions of pre-service science teachers regarding environmental problems through word association*
}

Elif Ozata Yucel",

Muhlis Ozkan,

Suggested Citation:

International Journal of Learning and Teaching 8

Abstract 
International Journal of Learning and Teaching 8

1. Introduction 
International Journal of Learning and Teaching 8

2. Method 
International Journal of Learning and Teaching 8

3. Findings

3.1. The causes of environmental problems 
There are a lot of problems caused by human beings in our environment. Environmental problems are the product of human beings.

Various problems emerge in the environment due to people's lack of awareness. The cause of environmental problems is covetous people.

Smoke caused by exhaust or factory chimneys leads to environmental problems.

The main reason for environmental problems is pollution caused by garbage and waste.

Noise and environmental pollution occur as factories and industry are just in the part of human life.

\subsection{The types of environmental problems}

Today's biggest problem is air pollution and noise pollution.

Pollution is the most important problem for the environment. 
There are a lot of environmental problems such as air pollution and soil pollution.

They are problems such as increase in human population, population, and global warming. Fire is the main environmental problem.

\subsection{The effects of environmental problems}

Environmental problems affect our life negatively Damage to the ozone layer puts our future in danger.

Environmental problems are disadvantageous for human life and society.

People are affected by environmental problems.

People blowing the horns in their cars to annoy apartment residents.

Environmental problems are the elements threatening the lives of living beings such as air pollution and soil pollution.

Environmental problems put the lives of living beings in danger by disrupting the balance of the ecosystem. 
3.4. The measures that can be taken against environmental problems

Everyone should be aware of environmental problems.

One of the best solutions to environmental problems is raising the awareness of people. Environmental problems can be solved only through love and education.

If we make our waste recyclable, we contribute to both our environment and our country.

\subsection{Worry and Pessimism}

A frightening future is waiting our children due to environmental problems. Environmental problems have become unavoidable.

3.6. Other 
International Journal of Learning and Teaching 8

4. Conclusion and discussion 
International Journal of Learning and Teaching 8

\section{References}

. International Journal of Scientific Knowledge (IJSK) 4

Environmental Education Research, 6

Hasan Ali Yucel Egitim Fakultesi Dergisi 12

Balıkesir Universitesi Fen Bilimleri Enstitusu

Dergisi, 5 
Journal of Biological Education 33

The Journal of Environmental Education

39

10

World Applied Sciences Journal, 12

Environmental Education, 15/16

Qualitative data analysis

Australian Journal of

Environmental Education Research, 8

International Journal of Environmental \&Science Education, 4

Educational Sciences: Theory \& Practice, in

press

E-International Journal of Educational Research, 5

Qualitative evaluation and research methods

- International Conference on New Trends in Education and Their Implications, Antalya.

Journal of Research in Science Teaching, 11

Journal of Biological Education, 36

Ilkogretim Online, 9

). Case study research design and methods 